\title{
PENGEMBANGAN BAHAN AJAR NEUROSAINS BERMUATAN PENDIDIKAN KARAKTER DENGAN MODEL INKUIRI
}

\author{
Ni Wayan Suniasih \\ Jurusan Pendidikan Guru Sekolah Dasar, Fakultas IImu Pendidikan \\ Universitas Pendidikan Ganesha \\ Singaraja, Indonesia \\ e-mail: niwayan.suniasih@undiksha.ac.id
}

\begin{abstract}
Abstrak
Tujuan dari penelitian ini adalah sebagai berikut: 1) mendeskripsikan kelayakan buku ajar neurosains bermuatan pendidikan karakter dengan model inkuiri yang dikembangkan dari segi validitas isi dan konstruks, 2) mendeskripsikan kelayakan buku ajar neurosains bermuatan pendidikan karakter dengan model inkuiri yang dikembangkan dari segi kepraktikasan penggunaan di kelas. Penelitian ini merupakan model Research and Development (R\&D) atau penelitian dan pengembangan. Penelitian dan pengembangan merupakan proses atau langkah-langkah ilmiah yang digunakan dalam meneliti, memproduksi atau menyempurnakan produk yang telah ada. Pengembangan ini mengacu pada model dari langkah-langkah Borg and Gall. Data dikumpulkan dengan menggunakan instrumen yang telah dirancang kemudian dianalisis secara deskriptif dengan teknik deskriptif kualitatif. Kualitas produk berupa buku ajar yang dikembangkan telah memenuhi kelayakan dari aspek validitas dan kepraktisan. Berdasarkan analisis dan pembahasan yang telah dipaparkan, maka simpulan dalam penelitian adalah sebagai berikut: 1) buku ajar neurosains bermuatan pendidikan karakter dengan model inkuiri yang dikembangkan telah memenuhi kelayakan dari segi validitas isi tergolong dalam kategori sangat baik dengan skor 4,55 dari skor maksimal sebesar 5,00 ; 2) buku ajar neurosains bermuatan pendidikan karakter dengan model inkuiri yang dikembangkan telah memenuhi kelayakan dari segi kepraktisan ditinjau dari aspek penggunaan waktu yang tergolong efesien, serta skor siswa yang diperoleh termasuk dalam kategori baik, yaitu sebesar 3,72 dari skor maksimal 5,00.
\end{abstract}

Kata kunci: bahan ajar, neurosains, pendidikan karakter, inkuiri.

\begin{abstract}
The purpose of this research is as follows: 1) to describe the feasibility of textbook of neurosciences containing character education with inquiry model developed in terms of content and construct validity, 2) to describe the feasibility of textbook of neurosciences characterized by character education inquiry that developed in terms of practicality of use in class. This research is a model of Research and Development (R\&D) or research and development. Research and development is a process or scientific steps used in researching, producing or improving existing products. This development refers to the model of Borg and Gall's steps. The data that have been obtained by using the instrument that has been designed then analyzed descriptively by qualitative descriptive technique. The quality of product in the form of teaching materials developed must meet the feasibility of aspects of validity, practicality. Based on the analysis and discussion that has been presented, then the conclusions in the study are as follows: 1) textbook neurosains charged character education with inquiry model developed has met the feasibility of the content validity contens belonging to the category very well with a score of 4.55 of the maximum score of $5.00 ; 2$ ) textbook of neurosciences characterized by character education inquiry model developed has fulfilled the feasibility in terms of practicality in terms of the use of time that is classified as efficient, and student scores obtained are included in either category, that is equal 3.72 from a maximum score of 5.00 .
\end{abstract}

Keywords: textbooks, neuroscience, character education, inquiry. 


\section{Pendahuluan}

Menurut Undang-Undang No 20 Tahun 2003, tujuan pendidikan Indonesia, yaitu: mengembangkan potensi peserta didik agar menjadi manusia yang beriman dan bertaqwa kepada Tuhan Yang Maha Esa, berahklak mulia, sehat, berilmu, cakap, kreatif, mandiri, dan menjadi warga Negara yang demokratis serta bertanggung jawab. Hal ini mencerminkan bahwa pendidikan disetiap jenjang, termasuk jenjang perguruan tinggi harus diselenggarakan secara sistematis dan disertai dengan pembentukan karakter peserta didik sehingga mampu bersaing, beretika, bermoral, sopan santun dalam berinteraksi dengan masyarakat.

Pengembangan berbagai karakter manusia Indonesia masih jauh dari harapan tujuan pendidikan nasional, sebab proses pembelajaran yang dilaksanakan selama ini lebih menekankan pada aspek kognitif yang mengutamakan pengetahuan dan ingatan atau intelligence quotient (IQ) namun kurang mengembangkan kemampuan emotional quotient (EQ), dan spiritual quotient (SQ). Rendahnya karakter peserta didik tercermin dari tayangan televisi seperti tawuran pelajar, tawuran mahasiswa, demonstrasi anarkis, pengerusakan lingkungan, kekerasan, kerusuhan, korupsi yang merambah disemua sektor. Pendidikan karakter bertujuan untuk membentuk, menanamkan, memfasilitasi dan mengembangkan nilai-nilai positif pada anak sehingga menjadi pribadi yang unggul dan bermartabat.

Jurusan Pendidikan Guru Pendidikan Anak Usia Dini (PG PAUD) Universitas Pendidikan Ganesha telah merancang serta memberlakukan kurikulum Kerangka Kualifikasi Nasional Indonseia (KKNI) secara utuh dan terbatas pada mahasiswa angkatan tahun ajaran 2016/2017. Menurut Permendikbud No.49/2014, KKNI adalah kerangka penjenjangan kualifikasi kompetensi yang dapat menyandingkan, menyetarakan, dan mengintegrasikan antara bidang pendidikan dan bidang pelatihan kerja serta pengalaman kerja dalam rangka pemberian pengakuan kompetensi kerja sesuai dengan struktur pekerjaan di berbagai sektor. Dengan diberlakukannya kurikulum KKNI diharapkan akan mampu mencetak lulusan yang siap menghadapi millennium development goals atau era globalisasi.

Dalam kurikulum PG PAUD telah ditetapkan satu mata kuliah yang bernama neourosains. Mata kuliah ini terdiri dari 3 sks. Mata kuliah ini membahas tentang pengkajian struktur otak dan sistem syaraf yang berkaitan dengan proses perkembangan dan stimulasi pembelajaran pada anak usia dini. Banyaknya beban materi dalam mata kuliah ini menuntut dosen untuk menerapkan pembelajaran yang tepat dan memfasilitasi mahasiswa dalam proses pembelajaran sehingga kompetensi mata kuliah dapat tercapai. Terbatasnya media dan sumber belajar mata kuliah Neurosains membuat pembelajaran kurang optimal. Kegiatan pembelajaran yang dilakukan selama ini dilakukan dengan membagikan topik-topik materi perkuliahan kepada setiap kelompok mahasiswa. Hanya saja pada pertemuan pertama, dosen menjelaskan satu topik untuk memberikan gambaran umum tentang mata kuliah neurosains. Anggota setiap kelompok terdiri atas 3-4 orang mahasiswa. Kelompok mahasiswa yang mendapat giliran mempresentasikan topik perkuliahan ditentukan dengan cara undian. Aspek-aspek yang menjadi penilaian antara lain adalah solusi pemecahan masalah, kemampuan mempresentasikan dan mempertahankan topik yang dibahas, serta hasil UTS dan UAS.

Makalah yang dibuat oleh setiap kelompok mahasiswa menunjukkan bahwa mahasiswa kurang terampil memecahkan suatu permasalahan. Mahasiswa hanya menggunakan satu buku sebagai sumber kajian karena kesulitan mendapatkan referensi lain untuk memperkaya pembahasannya dalam makalah. Akibatnya, pembahasan yang dibuat oleh mahasiswa sangat dangkal dan persis mengikuti urutan materi yang terdapat dalam satu buku sumber yang disediakan oleh dosen.

Untuk memperbaiki dan meningkatkan kualitas pembelajaran dan hasil belajar mahasiswa, maka diperlukan penyerasian proses pembelajaran yang didukung perangkat yang baik dengan melakukan pengembangan perangkat pembelajaran berupa buku ajar. Buku ajar merupakan salah satu bentuk bahan ajar, yang mana dalam penyusunannya perlu memperhatikan beberapa prinsip. Menurut Mulyasa (2006) prinsip-prinsip dalam penyusunan dan pemilihan materi pembelajaran meliputi prinsip relevansi, konsistensi, dan kecukupan. Prinsip relevansi artinya keterkaitan, materi pembelajaran hendaknya relevan 
atau ada kaitannya dengan pencapaian standar kompetensi dan kompetensi dasar. Misalnya, jika kompetensi yang diharapkan dikuasai siswa berupa menghafal fakta, maka materi pembelajaran yang diajarkan harus berupa fakta atau bahan hafalan. Prinsip konsistensi artinya keajegan. Jika kompetensi dasar yang harus dikuasai siswa empat macam, maka bahan ajar yang harus diajarkan juga harus meliputi empat macam. Prinsip kecukupan artinya materi yang diajarkan hendaknya cukup memadai dalam membantu siswa menguasai kompetensi dasar yang diajarkan.

Trianto (2007) berpendapat bahwa; bahan ajar yang dikembangkan dikatakan baik jika memenuhi tiga kriteria, yaitu: 1) aspek validitas (validity), (2) aspek kepraktisan (practicality), 3) keefektifan (affectiveness).

Buku ajar sebagai bahan ajar yang valid adalah bahan ajar yang layak digunakan. Validitas buku ajar dilihat berdasarkan validitas isi dan validitas kontruk. Dilihat dari validasi isi maksudnya buku ajar dikatakan valid jika pengembangannya dilandasi oleh rasional teoritik yang kuat. Sedangkan validasi konstruk maksudnya kajian buku ajar tersebut memiliki keterkaitan yang konsisten antara berbagai komponen yang ada pada model pembelajaran yang diterapkan. Suatu buku ajar yang dikembangkan dikatakan praktis jika dalam pelaksanaan pembelajaran mudah digunakan di kelas. Buku ajar yang praktis dalam implementasinya di lapangan akan sangat bergantung dari kemudahan dalam praktik di lapangan. Aspek kepraktisan hanya dapat dipenuhi jika praktisi atau dalam hal ini dosen dan mahasiswa menyatakan bahwa perangkat tersebut mudah diterapkan. Suatu perangkat dikatakan efektif jika mampu mencapai sasaran pembelajaran yang telah ditetapkan dalam artian dapat meningkatkan hasil belajar yang diharapkan dicapai oleh mahasiswa. Dalam penelitian ini buku ajar yang dikembangkan terbatas pada pemenuhan kriteria validitas dan kepraktisan dari buku ajar Neurosains.

Mengatasi kelemahan-kelemahan yang dihadapi dalam proses pembelajaran, maka perlu dilakukan inovasi pengembangan bahan ajar untuk mengoptimalkan proses pembelajaran. Prinsip-prinsip dalam pembelajaran berorientasi kurikulum KKNI sejalan dengan konsep pembelajaran inkuiri. Pembelajaran yang dilaksanakan dengan model inkuri meliputi beberapa langkah kegiatan seperti yang dikemukakan oleh Sanjaya (2013: 201) sebagai berikut: (1) orientation, fase orientasi dilaksanakan untuk memunculkan ketertarikan siswa terhadap proses pembelajaran (creates interest), memberikan motivasi, membangitkan keingintahuan (generates curiosity), dan membangun informasi baru dengan pengetahuan sebelumnya (prior knowledge); (2) merumuskan masalah, merumuskan masalah merupakan langkah membawa siswa pada suatu persoalan yang mengandung teka-teki; (3) merumuskan hipotesis, hipotesis adalah jawaban sementara dari suatu permasalahan yang sedang dikaji; (4) mengumpulkan data, mengumpulkan data adalah aktivitas menyaring informasi yang diperlukan dalam menguji hipotesis yang diajukan; (5) merumuskan kesimpulan, merumuskan kesimpulan merupakan proses mendeskripsikan temuan yang diperoleh berdasarkan hasil pengujian hipotesis.

Mencermati permasalahan yang telah diuraikan di atas maka dalam penelitian ini dilakukan pengembangan buku ajar neurosains bermuatan karakter dengan model inkuiri.

Berdasarkan uraian tersebut di atas, secara umum penelitian ini bertujuan menghasilkan perangkat pembelajaran bermuatan pendidikan karakter dengan model inkuiri yang valid dan praktis sehingga nantinya layak digunakan untuk buku ajar pada jurusan PGPAUD Universitas Pendidikan Ganesha. Secara spesifik tujuan dari penelitian ini adalah sebagai berikut. 1) Mendeskripsikan kelayakan buku ajar neurosains bermuatan pendidikan karakter dengan model inkuiri yang dikembangkan dari segi validitas isi dan konstruk. 2) Mendeskripsikan kelayakan buku ajar neurosains bermuatan pendidikan karakter dengan model inkuiri yang dikembangkan dari segi kepraktisan penggunaan di kelas.

\section{Metode}

Penelitian ini merupakan Research and Development (R\&D) atau penelitian dan pengembangan. Penelitian dan pengembangan merupakan proses atau langkah-langkah ilmiah yang digunakan dalam meneliti, memproduksi atau menyempurnakan produk yang telah ada. Pengembangan ini mengacu pada model dari langkah-langkah Borg and Gall. 
Terdapat sepuluh langkah-langkah Borg and Gall (Arifin, 2012). Selanjutnya, untuk dapat memahami tiap langkah tersebut dapat dijelaskan sebagai berikut.

Adapun skema atau gambaran tahapan pengembangan produk dari Borg and Gall adalah sebagai berikut:

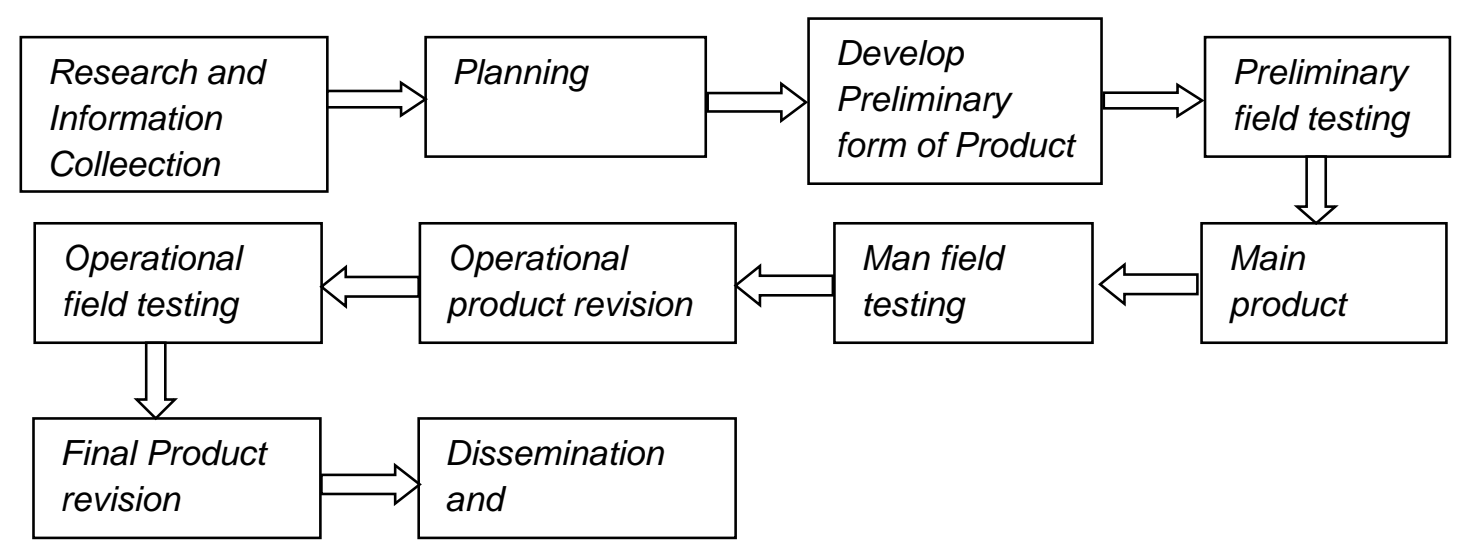

Gambar 01. Model Pengembangan Borg and Hall (Arifin, 2012)

Selanjutnya, untuk dapat memahami tiap langkah tersebut dapat dijelaskan sebagai berikut. 1) Research And Information Collecting (Penelitian dan pengumpulan data). Pada tahap ini dilakukan survey dan observasi. Tujuan dari survey dan observasi digunakan untuk menganalisis kebutuhan, mengindentifikasi faktor-faktor yang menimbulkan masalah sehingga perlu adanya pengembangan model baru. 2) Planning (Perencanaan). Melakukan perencanaan, artinya pada tahap ini adalah tahap merancang kegiatan produk yang dikembangkan untuk memecahkan masalah. Perencanaan pada penelitian ini adalah merancang model pembelajaran yang menyenangkan. 3) Develop Preliminary Form Of Product (Pengembangan draf produk). Pada tahap ini adalah mengembangkan produk awal, meliputi penyiapan materi, prosedur atau penyusunan buku pegangan, dan instrumen evaluasi. Proses penelitian dilakukan dengan validasi rancangan produk oleh pakar ahli dibidangnya. Hasil dari validasi tersebut digunakan untuk memperbaiki rancangan produk sebelum diuji cobakan. 4). Preliminary Field Testing (Uji coba lapangan awal). Tahap berikutnya merupakan tahap uji coba terbatas. Data yang diperoleh dari uji coba terbatas, kemudian dianalisis dan dievaluasi untuk memperbaiki produk pada penerapan berikutnya. Pengujian pada penelitian ini dilakukan pada beberapa orang mahasiswa, untuk memastikan kegiatan sesuai dengan karakteristik mahasiswa. 5) Main Product Revision (Merevisi hasil uji coba). Melakukan revisi utama terhadap produk didasarkan pada saransaran uji coba. Bila ada kendala dalam proses pelaksanaannya, dilakukan revisi kegiatan. 6) Main Field Testing (Uji coba lapangan). Setelah melaksanakan revisi, kegiatan diuji coba ke tahap yang lebih besar yakni uji coba lapangan. Proses dari tahap ini adalah untuk menerapkan implementasi produk sebagai produk yang dikembangkan dalam wilayah yang lebih luas dan kondisi yang lebih nyata. 7) Operasional Product Revision (Penyempurnaan produk hasil uji lapangan). Melakukan revisi pada produk yang siap dioperasionalkan, berdasarkan saran-saran dari uji coba untuk memperbaiki hal-hal yang masih kurang sesuai pada saat produk diterapkan. 8) Operational field testing (Uji lapangan operasional) Pada tahap ini dilakukan pengujian dengan jumlah populasi lebih besar dari uji coba sebelumnya. Pengujian ini untuk mengetahui efektivitas produk yang dihasilkan setelah dilakukan berbagai evaluasi dan revisi dari hasil uji coba sebelumnya. Pada pengujian ini dapat digeneralisir pada populasi penelitian yakni mahasiswa PGPAUD. 9). Final product revision (Revisi produk akhir). Pada tahap ini merupakan revisi produk akhir, sebelum produk siap dipublikasikan serta diterapkan di lapangan. Hasil dari data tersebut menjadi landasan untuk melakukan revisi produk final. 10) Dissemination and implementation (Diseminasi dan Implementasi). Tahap akhir pada langkah ini adalah distribusi produk. Distribusi produk yang 
dilakukan setelah melewati quality control, teknik analisis data, langkah-langkah dalam proses penelitian dan pengembangan.

Berdasarkan keterbatasan yang dirasakan, maka langkah-langkah dalam penelitian ini dibatasi sampai langkah ke-tujuh. Penelitian ini meniadakan langkah ke-delapan sampai kesepuluh didasari keterbatasan waktu penelitian.

Metode pengumpulan data yang digunakan dalam penelitian ini adalah sebagai berikut. 1) Metode wawancara digunakan dalam mendapatkan data awal sebagai bahan dasar yang dianalisis untuk pengembangan buku ajar. 2) Angket untuk validasi produk yang dilengkapi dengan rubrik penilaian, pada penelitian pengembangan ini digunakan untuk mendapatkan informasi yang lengkap mengenai kelayakan dari produk yang dikembangkan oleh para ahli sebagai validator. 3) Lembar Observasi dalam penelitian ini dilakukan untuk mengetahui pelaksanaan produk pengembangan yang diterapkan. Produk pengembangan berupa buku ajar bermuatan karakter dengan model inkuri.

Data yang telah didapatkan dianalisis untuk mengevaluasi validitas, dan kepraktisan buku ajar. Validitas buku ajar menyangkut validitas isi dan validitas konstruk. Untuk melihat validitas isi digunakan lembar validasi pendapat validator menggunakan skala 5 dengan kategori; skor 5 = sangat baik, skor $4=$ baik, skor $3=$ cukup, skor $2=$ kurang, dan skor $1=$ sangat kurang. Validitas buku ajar ditentukan dengan mengkonversikan rata-rata skor total menggunakan kriteria berikut.

Tabel 1. Kriteria Nilai Rata-rata Skala Lima

\begin{tabular}{ccl}
\hline Nilai & Interval skor & \\
\hline 5 & $>4,20$ & Kategori \\
4 & $3,41-4,20$ & Baik \\
3 & $2,61-3,40$ & Cukup \\
2 & $1,81-2,60$ & Kurang \\
1 & $\leq 1,80$ & Sangat kurang \\
\hline
\end{tabular}

(Widoyoko, 2009)

Dalam penelitian ini ditetapkan kelayakan produk minimal mencapai kategori baik sehingga produk layak digunakan dalam pembelajaran di kelas.

Kepraktisan bahan ajar yang dikembangkan diukur dari keterlaksanaan perangkat pembelajaran di kelas. Data kepraktisan buku ajar diperoleh dari hasil pengamatan serta respon mahasiswa terhadap buku ajar yang digunakan. Data yang diperoleh dianalisis untuk mendapatkan nilai kepraktisannya. Rata-rata skor dari pengamat dan respon mahasiswa dikonversi ke dalam Tabel 2.

Tabel 2. Kriteria Kepraktisan Bahan Ajar

\begin{tabular}{cc}
\hline Skor & Kategori \\
\hline $3,5 \leq \mathrm{Sr}<4,0$ & Sangat praktis \\
$2,5 \leq \mathrm{Sr}<3,5$ & Praktis \\
$1,5 \leq \mathrm{Sr}<2,5$ & Tidak praktis \\
$1,0 \leq \mathrm{Sr}<1,5$ & Sangat tidak praktis \\
\hline
\end{tabular}

Keterangan:

$\mathrm{Sr} \quad=$ skor rata-rata

$\mathrm{Sr}=\frac{\text { jumlah } \text { skor semua item }}{\text { banyak item }}$

Dalam penelitian ini buku ajar yang dikembangkan dikatakan memiliki nilai kepraktisan apabila rata-rata skor minimal mencapai kategori praktis atau berada pada interval $2,5 \leq \mathrm{Sr}<3$. 


\section{Hasil Penelitian dan Pembahasan}

Hasil dari penelitian ini berupa produk buku ajar, yaitu buku ajar neurosains bermuatan pendidikan karakter dengan model inkuiri. Hasil penelitian yang dipaparkan sesuai dengan tahapan penelitian yang telah dilakukan yaitu: (a) Research And Information Collecting (Penelitian dan pengumpulan data), (b) Planning (Perencanaan), (c) Develop Preliminary Form Of Product (Pengembangan draf produk), (d) Preliminary Field Testing (Uji coba lapangan awal), (e) Main Product Revision (Merevisi hasil uji coba), (f) Main Field Testing (Uji coba lapangan). Adapun penjelasan lebih lengkap mengenai prosedur penelitian di atas adalah sebagai berikut.

\section{a. Research And Information Collecting (Penelitian dan Pengumpulan Data)}

Pada tahap ini dilakukan observasi serta pengkajian bahan ajar yang sudah dimiliki atau yang sering digunakan oleh pengajar mata kuliah neurosains dan buku pegangan yang digunakan mahasiswa, serta penilaian yang dilakukan dosen pengampu mata kuliah neurosains. Berdasarkan hasil observasi, wawancara dengan dosen pengampu mata kuliah neurosians, serta mahasiswa yang telah mengambil mata kuliah neurosains diperoleh beberapa permasalahan berikut ini:

1) Bahan ajar yang digunakan oleh dosen pengampu mata kuliah mengandalkan buku dari cetakan penerbit dan jurnal.

2) Kegiatan pembelajaran yang dilakukan pada mata kuliah neurosains selama ini dilakukan dengan membagikan topik-topik materi perkuliahan kepada setiap kelompok. Hanya saja pada pertemuan pertama, dosen menjelaskan satu topik untuk memberikan gambaran umum tentang mata kuliah. Anggota setiap kelompok terdiri atas dua orang mahasiswa. Kelompok mahasiswa yang mendapat giliran mempresentasikan topik perkuliahan ditentukan dengan cara undian. Makalah yang dibuat oleh setiap kelompok mahasiswa menunjukkan bahwa mahasiswa kurang terampil memecahkan suatu permasalahan. Mahasiswa kurang berusaha mencari referensi lain untuk memperkaya pembahasannya dalam makalah. Akibatnya, pembahasan yang dibuat oleh mahasiswa sangat dangkal dan persis mengikuti urutan materi yang terdapat dalam satu buku sumber yang disediakan oleh dosen. Makalah yang dibuat oleh setiap kelompok mahasiswa juga menunjukkan bahwa mahasiswa kurang mengembangkan keterampilan berpikir kritis. Hal ini ditunjukkan oleh mahasiswa tidak mampu memberikan argumen secara akurat terhadap suatu masalah yang dibahas. Argumen yang disajikan oleh mahasiswa sangat sederhana dan belum mampu menghasilkan argumen yang kompleks. Kemampuan mahasiswa dalam menganalisis suatu permasalahan menjadi beberapa permasalahan yang lebih sederhana masih sangat sulit dilakukan. Mahasiswa memecahkan masalah secara langsung tanpa mengidentifikasi terlebih dahulu asumsi yang diperlukan untuk memecahkan masalah. Demikian juga, mahasiswa mengalami kesulitan mempertimbangkan atau mengevaluasi suatu pendapat.

3) Belum adanya bahan ajar neurosains yang sesuai dengan deskripsi kurikulum Jurusan PG PAUD. Selama ini masih mengandalkan buku penerbit atau jurnal sehingga menyulitkan mahasiswa untuk mencari materi secara komprehensif.

4) Jarangnya menggunakan model pembelajaran dengan pendekatan saintifik, seperti model pembelajaran inkuri.

5) Proses pembelajaran tidak secara langsung melatihkan karakter mahasiswa.

Berdasarkan beberapa permasalahan yang dipaparkan di atas, peneliti tertarik untuk mengembangkan buku ajar neurosains bermuatan pendidikan karakter dengan model inkuiri sehingga pembelajaran bisa lebih efektif dan efisien.

\section{b. Planning (Perencanaan)}

Pada tahap ini dilaksanakan pengumpulan seluruh informasi yang dapat digunakan sebagai bahan untuk pembuatan produk, dalam hal ini buku ajar yang diharapkan dapat mengatasi permasalahan yang ada. Selanjutnya dilakukan analisis terhadap capaian mata kuliah (CP) pada silabus jurusan PG PAUD Universitas Pendidikan Ganesha yang dijadikan 
acuan untuk menentukan materi yang dipilih. Adapun materi yang dipilih untuk dirancang sebagai buku ajar neurosains bermuatan pendidikan karakter dengan model inkuiri.

Tabel 3 Rancangan Materi Perencanaan Buku Ajar

\begin{tabular}{|c|c|c|}
\hline No & $\begin{array}{l}\text { Indikator Pencapaian } \\
\text { (kemampuan akhir yg diharapkan) }\end{array}$ & Bahan Kajian/Materi Pokok \\
\hline 1 & $\begin{array}{l}\text { Mahasiswa mampu memahami hakikat } \\
\text { neurosains dalam pembelajaran anak, } \\
\text { mengkaji dan memahami hakikat } \\
\text { neurosains dalam pembelajaran anak }\end{array}$ & $\begin{array}{l}\text { 1. Memahami pengertian neurosains } \\
\text { 2. Memahami tujuan pembelajaran neurosains } \\
\text { 3. Mampu memahami ruang lingkup } \\
\text { neurosains } \\
\text { 4. Mampu menjelaskan neurosains dan } \\
\text { implikasinya dalam pembelajaran }\end{array}$ \\
\hline 2 & $\begin{array}{l}\text { Mahasiswa mampu mengkaji dan } \\
\text { memahami bagaimana struktur otak dan } \\
\text { sistem syaraf }\end{array}$ & $\begin{array}{l}\text { 1. Memahami proses terbentuknya otak } \\
\text { manusia } \\
\text { 2. Memahami tahapan perkembangan otak } \\
\text { anak } \\
\text { 3. Mampu memahami sstem saraf pusat } \\
\text { 4. Memahami perbedaan fungsi otak kiri dan } \\
\text { otak kanan } \\
\text { 5. Mampu menjelaskan neuron (saraf) }\end{array}$ \\
\hline 3 & $\begin{array}{l}\text { Mahasiswa mampu menelaah } \\
\text { perkembangan otak terkait: } \\
\text { 1. Multiple Intelligence } \\
\text { 2. Indera penciuman }\end{array}$ & $\begin{array}{l}\text { 1. Perkembangan otak dan multiple intelligence } \\
\text { 2. Indera penciuman }\end{array}$ \\
\hline
\end{tabular}

c. Develop Preliminary Form Of Product (Pengembangan draf produk)

Pada tahap ini adalah mengembangkan produk awal, meliputi penyiapan materi, prosedur atau penyusunan bahan ajar, dan instrumen evaluasi. Proses penelitian dilakukan dengan validasi rancangan produk oleh pakar ahli dibidangnya. Hasil dari validasi tersebut digunakan untuk memperbaiki rancangan produk sebelum diuji cobakan.

Draft awal yang telah dibuat pada tahap selanjutnya divalidasi oleh para praktisi dengan tujuan untuk memperoleh masukan atau saran untuk perbaikan draft yang telah dibuat sebelum dilakukan uji coba secara empiris. Saran hasil validasi bahasa dapat dilihat pada Tabel 3, serta ringkasan hasil penilaian dari para praktisi dapat dilihat Tabel 4

Tabel 4 Saran Hasil Validasi Bahasa Terhadap Buku

\begin{tabular}{cl}
\hline No & \\
\hline 1 & Penulisan cover pada buku siswa disesuaikan dengan EYD \\
2 & Konsitensi penggunaan symbol dalam buku siswa. \\
3 & Penulisan untuk petunjuk kegiatan sesuaikan dengan EYD \\
4 & Perbaikan deskripsi masalah pada kegiatan unit IV, belum sesuai dengan tujuan kegiatan \\
5 & Kesalahan beberapa tata tulis perlu dilakukan cek lebih hati-hati. \\
\hline
\end{tabular}

Tabel 5 Ringkasan Hasil Validasi Buku Ajar

\begin{tabular}{clcl}
\hline No & \multicolumn{1}{c}{ Aspek Validasi } & Rata-Rata & Kategori \\
\hline 1 & Isi buku ajar & 4.43 & Sangat baik \\
2 & $\begin{array}{l}\text { Cara penyajian buku secara } \\
\text { umum }\end{array}$ & 4.47 & Sangat baik \\
3 & $\begin{array}{l}\text { Bentuk fisik buku secara } \\
\text { umum }\end{array}$ & 4.75 & Sangat baik \\
\hline & Rata-rata & $\mathbf{4 . 5 5}$ & Sangat baik \\
\hline
\end{tabular}

Hasil validasi isi terhadap buku ajar didapatkan rata-rata 4,55 atau berada dalam kategori sangat baik. Dalam penelitian ini ditetapkan kelayakan minimal validasi isi buku ajar mencapai kategori baik. Hasil validasi ini menunjukkan buku ajar layak digunakan dalam pembelajaran di kelas. 
Masukan atau saran yang diperoleh pada tahap validasi digunakan sebagai acuan untuk menyempurnakan draft buku ajar yang telah dibuat.

\section{d. Preliminary Field Testing (Uji coba lapangan awal)}

Tahap berikutnya merupakan tahap uji coba terbatas. Data yang diperoleh dari uji coba terbatas, kemudian dianalisis dan dievaluasi untuk memperbaiki produk pada penerapan berikutnya. Pengujian pada penelitian ini dilakukan pada beberapa orang mahasiswa Jurusan PG PAUD Kelas C Semester V, untuk memastikan kegiatan buku ajar sesuai dengan tuntutan kurikulum. Secara umum dalam uji coba terbatas tidak terdapat masukan yang signifikan sehingga draf buku layak digunakan dalam proses pembelajaran di kelas.

\section{e. Main Product Revision (Merevisi hasil uji coba)}

Tahap berikutnya adalah melakukan revisi utama terhadap produk didasarkan pada saran-saran uji coba. Berdasarkan hasil uji coba, karena tidak ada kendala dalam proses pembelajaran yang dilakukan di kelas, sehingga tidak dilakukan revisi pada draf buku ajar. Dengan kata lain draf buku ajar ini sudah menjadi draf final dapat digunakan dalam pembelajaran di kelas (uji coba lapangan).

\section{f. Main Field Testing (Uji coba lapangan)}

Setelah revisi, diuji coba ke tahap yang lebih besar yakni uji coba lapangan. Proses dari tahap ini adalah untuk implementasi produk sebagai produk yang dikembangkan dalam wilayah yang lebih luas dan kondisi yang lebih nyata. Kegiatan ini dilakukan pada semester III Kelas C Jurusan PG PAUD Undiksha. Pengujian ini bertujuan untuk mengetahui kepraktisan bahan ajar yang dikembangkan. Selama proses pembelajaran tidak ditemukan kendala yang berarti dalam penggunaan buku ajar neurosains bermuatan pendidikan karakter dengan model inkuiri. Data kepraktisan buku ajar diukur dengan membagikan kuisioner diakhir proses pembelajaran. Adapun data hasil pengukuran dapat dilihat pada Tabel 6.

Tabel 6. Ringkasan Respon Mahasiswa Terhadap Buku Ajar

\begin{tabular}{|c|c|c|c|}
\hline \multirow{2}{*}{\multicolumn{2}{|c|}{ Aspek yang ditanyakan }} & \multicolumn{2}{|c|}{ Hasil Penilaian } \\
\hline & & $\begin{array}{c}\text { Rata-rata } \\
\text { skor }\end{array}$ & Kriteria \\
\hline 1) & Saya senang belajar dengan menggunakan buku ini & 3.61 & Baik \\
\hline 2) & Tampilan buku ini menarik & 3.67 & Baik \\
\hline 3) & Isi buku ini menarik untuk dibaca & 3.94 & Baik \\
\hline 4) & $\begin{array}{l}\text { Saya merasa tertantang untuk menemukan masalah } \\
\text { tentang materi }\end{array}$ & 3.94 & Baik \\
\hline 5) & $\begin{array}{l}\text { Dengan membaca buku ini saya terbantu untuk } \\
\text { menemukan jawaban sementara dari masalah yang } \\
\text { saya temukan }\end{array}$ & 4.03 & Baik \\
\hline 6) & $\begin{array}{l}\text { Penyajian materi pada buku ajar ini terurut dengan } \\
\text { rapi sehingga mudah saya pahami }\end{array}$ & 3.56 & Baik \\
\hline 7) & $\begin{array}{l}\text { Melalui buku ajar ini, saya menjadi lebih mudah } \\
\text { memahami materi yang diberikan }\end{array}$ & 3.92 & Baik \\
\hline 8) & $\begin{array}{l}\text { Melalui buku ajar ini, saya mendapatkan pemahaman } \\
\text { yang medalam dari materi yang dipelajari }\end{array}$ & 3.89 & Baik \\
\hline 9) & $\begin{array}{l}\text { Memalui buku ajar ini, saya mendapatkan } \\
\text { pengetahuan luas tentang materi yang saya pelajari }\end{array}$ & 3.42 & Baik \\
\hline 10) & Tugas yang harus saya kerjakan dalam buku ini jelas & 3.86 & Baik \\
\hline 11) & Tugas-tugas pada buku ini tidak membebani saya & 3.75 & Baik \\
\hline & $\begin{array}{l}\text { Buku ini dapat membantu saya dalam berinteraksi } \\
\text { dengan guru maupun siswa yang lain }\end{array}$ & 3.75 & Baik \\
\hline & $\begin{array}{l}\text { Melalui buku ini, saya dapat menyelesaikan masalah } \\
\text { yang diberikan baik secara individu maupun } \\
\text { kelompok }\end{array}$ & 3.56 & Baik \\
\hline
\end{tabular}




\begin{tabular}{ccc}
\hline \multicolumn{1}{c}{ Aspek yang ditanyakan } & \multicolumn{2}{c}{ Hasil Penilaian } \\
& $\begin{array}{c}\text { Rata-rata } \\
\text { skor }\end{array}$ & Kriteria \\
\hline 14) Buku ini dapat memberikan saya kenyamanan dalam & 3.72 & baik \\
belajar & & \\
15) Karakter yang ingin dilatihkan dalam buku ini mudah & 3.92 & Baik \\
$\begin{array}{l}\text { saya pahami } \\
\text { 16) Kalimat yang digunakan dalam buku ini mudah } \\
\text { dipahami }\end{array}$ & 3.83 & Baik \\
17) Gambar maupun tabel yang digunakan pada buku ini & 3.81 & Baik \\
jelas & & \\
18) Dengan adanya buku ini, saya menjadi lebih \\
$\begin{array}{l}\text { mengetahui akan manfaat dari materi yang telah } \\
\text { dipelajari serta karakter apa yang perlu dilatihkan } \\
\text { setiap kita belajar }\end{array}$ & 3.56 & Baik \\
19) Saya ingin selalu mempraktekkan nilai-nilai karakter \\
$\begin{array}{l}\text { yang ada di dalam buku ini. } \\
\text { Rata-rata total }\end{array}$ & 3.69 & Baik \\
\end{tabular}

Berdasarkan tabel di atas terlihat bahwa rata-rata skor yang diperoleh dari respon gsiswa terhadap bahan ajar yang dikembangkan adalah 3,76 dari skor maksimum 5,00. Berdasarkan kriteria kepraktisan yang telah diuraikan, dapat dikatakan bahwa bahan ajar praktis (baik) digunakan dalam pembelajaran.

\section{Pembahasan}

Berdasarkan hasil penelitian yang diperoleh menunjukkan bahwa bahan ajar yang dikembangkan telah memenuhi kualitas yang baik dari segi validitas dan kepraktisan. Berikut ini dipaparkan pembahasan lebih lanjut tentang validitas bahan ajar dan tingkat kepraktisan pembelajaran.

\section{Validitas Buku Ajar Neurosains Bermuatan Pendidikan Karakter Dengan Model Inkuiri}

Validasi buku ajar ditempuh melalui validasi isi dari para pakar dan validasi empiris. Hasil penilaian validasi isi terhadap buku ajar didapatkan rata-rata 4,55 atau berada dalam kategori sangat baik. Hasil pengembangan bahan ajar dalam penelitian ini berada dalam kategori sangat baik, disebabkan oleh beberapa faktor antara lain sebagai berikut.

(a) Buku ajar yang dikembangkan telah sesuai dengan tuntutan kurikulum KKNI, yaitu pengembangan bahan ajar berorientasi pada pendekatan inquiry, discovery, serta problem base learning. Dimana dalam penelitian ini buku ajar yang dikembangkan dengan model inkuiri. Selain itu, pemilihan topik, kedalaman materi dan langkah-langkah pembelajaran yang disusun telah mengacu pada capaian pembelajaran yang ada pada kurikulum KKNI.

(b) Buku ajar yang dikembangkan disesuaikan dengan aspek-aspek pengukuran validitas yaitu validitas isi. Dalam pengembangan buku ajar ini didapatkan validitas isi dan validitas konstruk dalam kategori valid. Pemenuhan validitas isi artinya pengembangan buku ajar telah didasarkan atas isi materi dan teori-teori yang dijadikan acuan dalam perumusan ataupun penyusunan. Sedangkan buku ajar yang memenuhi validitas konstruk berarti dalam pengembangannya memperhatikan keterkaitan antara komponen bahan ajar tersebut dan disusun secara sistematis. Dengan adanya kegiatan mahasiswa pada buku ajar memungkinkan mahasiswa mengkonstruksi sendiri pengetahuannya sesuai dengan sub materi yang diberikan sehingga mahasiswa menjadi penemu dan pemilik ilmu bukan sekedar pengguna atau penghafal pengetahuan.

(c) Komponen-komponen buku ajar yang dikembangkan sesuai dengan indikator yang telah ditetapkan pada instrumen validasi. Hal ini berarti penyajian buku ajar secara umum baik dari segi tampilan, isi materi, dan penggunaan bahasa telah memenuhi dan sesuai dengan indikator yang menjadi acuan dalam menilai kualitas bahan ajar. 
Faktor-faktor tersebut di atas menyebabkan buku ajar yang dikembangkan telah memenuhi kriteria valid sesuai dengan yang diharapkan, baik dari segi isi maupun konstruknya, sehingga layak untuk digunakan dalam pembelajaran.

Meskipun sudah memenuhi kriteria valid sehingga layak digunakan dalam pembelajaran, bahan ajar ini masih memiliki kelemahan karena uji validasi yang dilakukan hanya menggunakan praktisi tiga orang dosen saja. Sehingga hal ini yang menjadikan alasan minimnya masukan atau saran dari para validator.

\section{Tingkat Kepraktisan Buku Ajar Neurosains Bermuatan Pendidikan Karakter dengan Model Inkuiri}

Kepraktisan bahan ajar dapat diketahui dari respon siswa terhadap buku ajar. Kepraktisan ini menunjukkan kemudahan siswa dalam menggunakan buku ajar yang dikembangkan sesuai dengan alokasi waktu yang telah ditentukan, begitu juga dengan alat, bahan, serta media yang digunakan dalam pembelajaran mudah didapatkan serta mudah digunakan sehingga mahasiswa memberikan respon positif terhadap pembelajaran yang telah dilakukan. Berdasarkan hasil data observasi penggunaan waktu serta skor rata-rata respon mahasiswa menunjukkan bahwa buku ajar yang dikembangkan termasuk dalam kategori praktis. Meskipun demikian, selama proses implementasi bahan ajar berlangsung terlihat juga terdapat beberapa kendala.

Pada pertemuan pertama, secara umum proses implementasi buku ajar belum berlangsung secara optimal. Hal ini terlihat dari penggunaan waktu untuk masing-masing tahapan pembelajaran tidak sesuai dengan perencanaan kegiatan pembelajaran yang ada pada buku. Dalam kegiatan pembelajaran yang ada pada buku, pertemuan pertama dirancang selama 100 menit dengan tiga tahapan kegiatan, yaitu pendahuluan 15 menit, kegiatan inti 60 menit serta kegiatan penutup 15 menit. Pada pertemuan pertama untuk kegiatan pendahuluan sesuai dengan rancangan pada kegiatan pembelajaran namun pada kegiatan inti waktu yang dihabiskan 105 menit. Hal ini berpengaruh pada tidak maksimalnya proses pembelajaran pada kegiatan penutup. Adapun kendala yang ditemui dalam pertemuan pertama sebagai penyebab ketidaksesuaian rancangan pada kegiatan pembelajaran dengan implementasi di lapangan antara lain.

a) Dalam melakukan kegiatan pada buku ajar kebanyakan mahasiswa masih kelihatan kebingungan dalam melakukan kegiatan.

b) Dalam kegiatan diskusi, terlihat dari beberapa kelompok belum mampu bekerja dalam kelompok

c) Dalam kegiatan presentasi kelompok, kelompok yang tidak menyajikan hasil diskusi tidak mau menanggapi hasil presentasi.

d) Mahasiswa masih bingung dalam proses pembelajaran sehingga masih banyak memberikan kata kunci dalam proses pembelajaran.

Bertolak dari kendala-kendala yang dihadapi pada pertemuan pertama, maka peneliti bersama pengamat melakukan diskusi dengan rancangan solusi yang digunakan dalam pertemuan kedua. Rancangan penanganan mahasiswa dengan yang diberikan berdasarkan hasil diskusi adalah.

1) Peneliti berusaha memberikan motivasi kepada mahasiswa dengan meminta untuk mencermati deskripsi kegiatan yang ada pada buku ajar.

2) Dosen memberikan bantuan kepada mahasiswa dalam kegiatan diskusi kelompok apabila ada hal-hal yang tidak dimengerti, dengan cara mendatangi ke setiap kelompok.

3) Menyadari bahwa dosen di dalam kelas bertugas sebagai fasilitator dalam pembelajaran. Oleh karena itu tidak dibenarkan dosen lebih mendominasi proses pembelajaran. Pembelajaran harus lebih diarahkan pada student center bukan teacher center, sehingga diharapkan mahasiswa dapat mengkonstruksi sendiri pengetahuan yang dipelajari. 
4) Memberikan kesempatan kepada kelompok lain yang tidak bertugas sebagai penyaji hasil diskusi untuk memberikan tanggapan. Hal ini bertujuan untuk menemukan hasil pemecahan masalah yang tepat.

Pembelajaran pertemuan kedua disesuaikan dengan hasil refleksi pertemuan pertama. Berdasarkan hasil refleksi pada pertemuan kedua ada beberapa perubahan yang menuju kearah positif dibandingkan pada pertemuan pertama antara lain: 1) mahasiswa sudah bisa melakukan kegiatan sesuai dengan petunjuk kegiatan, 2) dosen mulai terbiasa melakukan langkah-langkah pembelajaran sesuai dengan yang ada di kegiatan pembelajaran, 3) dosen sudah mulai memposisikan diri sebagai fasilitator, 4) dosen sudah mendatangi kelompok-kelompok yang masih kelihatan kebingungan dalam mengerjakan kegiatan, 5) dosen mulai memberikan kesempatan kepada kelompok yang tidak menyajikan hasil diskusi untuk menanggapi hasil presentasi.

Pada pertemuan kedua meskipun kendala yang pertama mampu teratasi dengan baik masih ada beberapa kendala yang dialami pada pertemuan kedua, antara lain:

1) Masih tidak sesuainya waktu antara perencanaan kegiatan pembelajarandengan implementasi. Pada kegiatan pendahuluan diperlukan waktu 10 menit, kegiatan inti 100 menit dan kegiatan penutup 5 menit.

2) Laporan kegiatan yang disusun oleh mahasiswa, ada beberapa kelompok yang belum mampu membuat laporan sesuai dengan pentunjuk kegiatan.

3) Ada mahasiswa dalam kelompok yang masih kelihatan pasif dan tidak aktif dalam kegiatan diskusi.

4) Mahasiswa belum mampu memanfaatkan waktu dengan efektif sehingga kegiatan siswa berakhir tidak sesuai dengan perencanaan waktu yang dialokasikan.

Perbaikan yang dilakukan untuk pertemuan kedua, peneliti dengan pengamat melakukan diskusi dalam upaya mencari solusi terhadap kendala-kendala yang dihadapi.

1) Menjelaskan kepada mahasiswa tentang alokasi waktu masing-masing kegiatan.

2) Memberikan penjelasan kepada kelompok cara membuat laporan sesuai dengan format laporan yang ditetapkan.

3) Memberikan motivasi kepada mahasiswa yang belum mampu berpatisifasi aktif dalam kelompok diskusi.

4) Memberikan arahan kepada mahasiswa supaya siswa melakukan kegiatanefektif dan efisien sesuai dengan alokasi waktu yang diberikan supaya timbul rasa tanggung jawab dan percaya diri.

Pembelajaran pertemuan ketiga disesuaikan dengan hasil refleksi pertemuan kedua. Pada pertemuan ketiga sampai ke lima sudah menunjukkan pemakaian waktu yang lebih efesien dan sesuai dengan alokasi waktu pada buku ajar. Hal ini menunjukkan implementasi buku ajar pada pertemuan ketiga sampai kelima secara umum sudah berdampak positif setelah dilakukan perbaikan-perbaikan. Mahasiswa sudah mampu melakukan kegiatan pembelajaran sesuai dengan rancangan waktu dan kegiatan yang ada pada kegiatan pembelajaran. Selain itu, mahasiswa dan dosen sudah kelihatan sangat terbiasa dengan model pembelajaran yang digunakan. Bahkan siswa sudah mulai mencantumkan sumber belajar dari internet dalam laporan yang dibuat.

Sementara itu, kepraktisan bahan ajar juga dilihat dari respon mahasiswa terhadap buku ajar, dari hasil penelitian didapatkan nilai respon mahasiswa sebesar 3.72 yang berarti buku mahasiswa praktis (baik) digunakan oleh mereka.

Secara umum, pengembangan buku ajar ini telah memenuhi syarat kepraktisan yaitu berada dalam kategori baik/praktis. Berdasarkan hasil refleksi dari kelima pertemuan yang telah dilakukan, maka ada beberapa hal positif yang terjadi selama pembelajaran, yaitu:

1) Buku ajar membantu dosen dalam pembelajaran karena dalam buku ini berisi langkah-langkah pembelajaran yang harus dilaksanakan dalam proses pembelajaran di kelas.

2) Mahasiswa mulai terbiasa melakukan kegiatan (tugas) serta membuat laporan secara ilmiah sehingga nantinya memudahkan mahasiswa untuk membuat laporan ilmiah pada kegiatan dan topik pelajaran lain. 
3) Menumbuhkan sikap kerjasama dan tanggung jawab melalui kerja kelompok yang dirancang dalam proses pembelajaran.

4) Memberikan pengalaman kepada mahasiswa tentang perubahan paradigma belajar dari teacher centered menjadi student centered.

Berdasarkan uraian di atas dapat disimpulkan bahwa pengembangan buku ajar neurosains bermuatan pendidikan karakter dengan model inkuiri yang dikembangkan telah memenuhi syarat kepraktisan bahan ajar, sehingga layak digunakan oleh dosen untuk buku pegangan dan buku mahasiswa layak digunakan sebagai buku pegangan mahasiswa.

Berdasarkan analisis dan pembahasan yang telah dipaparkan, maka simpulan dalam penelitian adalah (1) Buku ajar neurosains bermuatan pendidikan karakter dengan model inkuiri yang dikembangkan telah memenuhi kelayakan dari segi validitas isi tergolong dalam kategori sangat baikdengan skor 4,55 dari skor maksimal sebesar 5,00. (2) Buku ajar neurosains bermuatan pendidikan karakter dengan model inkuiri yang dikembangkan telah memenuhi kelayakan dari segi kepraktisan yang ditinjau dari aspek penggunaan waktu yang tergolong efesien, serta skor siswa yang diperoleh termasuk dalam kategori baik, yaitu sebesar 3,72 dari skor maksimal 5,00.

Mengacu pada rumusan masalah dan didukung oleh hasil penelitian dalam penelitian ini, dapat diajukan saran sebagai berikut. (1) Dalam penelitian ini telah dihasilkan Buku ajar neurosains bermuatan pendidikan karakter dengan model inkuiri. Agar diperoleh buku ajar yang baik perlu penyempurnaan buku ajar yang telah dikembangkan ini, perlu dilakukan uji coba buku ajar ini pada kelas, yang berbeda dengan karakteristik yang sama atau setara dengan kelas eksperimen. (2) Buku ajar ini sangat praktis digunakan oleh mahasiswa sehingga dalam pengembangan buku ajar yang lain dapat mengacu pada pengembangan buku ajar ini.

\section{Daftar Pustaka}

Anzwar. 2003. Reliabilitas dan Validitas. Yogyakarta: Liberty.

Agung, A.A. Gede. 2015. Statistik Dasar untuk Pendidikan. Yogyakarta: Deepublish.

Arifin Zainal. 2012. Penelitian Pendidikan metode dan Paradigma Baru. Bandung: Remaja Rosda Karya.

Candiasa, I M. 2004. Analisis Butir Desertasi Aplikasi dengan Iteman, Bigsteps dan SPSS. Singaraja: Unit Penerbitan IKIP Negeri Singaraja.

Candiasa, I M. 2007. Statistik Multivariat Disertai Petunjuk Analisis dengan SPSS. Singaraja: Program Pasca Sarjana Universitas Pendidikan Ganesha.

Chodijah, S. 2012. Pengembangan Perangkat Pembelajaran Fisika Menggunakan Model Guided Inquiry Dilengkapi Penilaian Portofolio pada Materi Gerak Melingkar. Jurnal Penelitian Fisiska, diakses 25 maret 20017.

Human Development Report $2016 \mathrm{http} / / / \mathrm{hdr}$.undp.org/sites/all/themes/hdr_theme/countrynotes/IDN.pdf, diakse tanggal 26 Maret 2017.

Gregory, Ribert J. 2000. Psychological Testing (History, Principles, and Application). Bonston: Allyn and Bacon.

Gunter, A.L., et al. 1990. Intruction a Model Approach. London: Allyn and Bacon.

Jaya, M. I. 2013. Pengembangan Perangkat Pembelajaran Biologi Bermuatan Pendidikan Karakter dengan Setting Guided Inquiri untuk Meningkatkan Karakter dan Hasil Belajar Siswa SMP.Tesis. Program Pasca Sarjana.

Mulyasa E. 2006. Kurikulum yang Disempurnakan. Bandung: PT. Remaja Rosdakarya.

Sadra,I W. 2007. PengembanganPembelajaran Matematikan Berwawasan Lingkungan dalam Pelatihan Guru Kelas I SD. Desertasi (tidak diterbitkan). Surabaya: UNESA.

Sanjaya, Wina. 2013.Kurikulum dan Pembelajaran. Bandung: Kencana Prenada Media Group.

Saraswati, Lili, N. 2013. Pengaruh Model Pembelajaran Inkuiri Terhadap Hasil Belajar Matematika Siswa Kelas III SD Gugus I Kecamatan Buleleng. Diakses dari http://ejournalundiksha.ac.id/index.php/JJPGSD/artilce/dpwnload/713/586, diakses 8 April 2017 
Sugiyono. 2011. Metode Penelitian Kuantitatif Kualitatif dan R\&D. Bandung: Alfabeta.

Trianto. 2007. Model-model Pembelajaran Inovatif Berorientasi Kontruktivistik. Jakarta: Prestasi Pustaka.

Trianto. 2010. Model Pembelajaran Terpadu-Konsep, Strategi, dan Implementasinya dalam Kurikulum Tingkat Satuan Pendidikan (KTSP). Surabaya: Bumi Aksara

Zubaedi. 2011. Desain Pendidikan Karakter. Jakarta: Kencana Prenada Media Group. Wena Made. 2012. Strategi Pembelajaran Inovatif Kontemporer. Jakarta: Bumi Aksara.

Widoyoko, E. P. 2009. Evaluasi Program Pembelajaran. Pustaka Pelajaran: Yogyakarta 